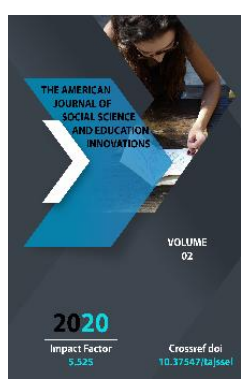

Copyright: Original content from this work may be used under the terms of the creative commons attributes 4.0 licence.

\section{Definition Of The Principles Of Teaching Preschool Children}

\author{
Abdullayev Abduqayum Abdulkhayevich \\ Associate Professor, Head Of Chair, Chirchiq State Pedagogical Institute, Uzbekistan \\ Shonasirova Zakhro Yuldashevna \\ Lecturer, Chirchiq State Pedagogical Institute, Uzbekistan \\ Mutalova Dilnoza Abdurashidovna \\ Lecturer, Chirchiq State Pedagogical Institute, Uzbekistan
}

\title{
ABSTRACT
}

In the article discusses the definition of the principles of teaching preschool children. As we know, teaching and upbringing, the peculiar aspects of a single process have their own composition, their own specific methods, their material and psychological prerequisites. In the early stages of children's life, education and upbringing appear in a closer unity, and it is difficult to differentiate them, but as the child grows up, upbringing and education become more and more clearly differentiated. But this does not mean at all that teaching loses its educational power, and education ceases to be teaching. The principles of teaching are not once and for all accepted categories. As psychological and pedagogical science develops, they improve, acquiring a deeper justification (the principle of active learning, developing learning, etc.).

\section{KEYWORDS}

Principles of teaching preschool children, pedagogical science, psychological science, method of teaching, foreign experience.

\section{INTRODUCTION}

The organizational form of teaching is classes that differ from lessons at school in structure, less stringent requirements, a greater degree of cooperation between the teacher and children. The main feature of training sessions with preschoolers is that cognitive activity is based on the child's practical, mental actions and mental actions with prompts. However, the general laws and principles of teaching preschool children and primary school children are the same. Knowledge of these principles ensures the productivity of solving educational, upbringing and developmental problems. 
Preschool education is an integral part and the first link in a unified system of continuous education, where the foundations of the personality are being formed. In accordance with the generally accepted age periodization of human development, preschool childhood covers the period from birth to 6 years old, when the child's motor, sensory and intellectual spheres are actively formed, and his speech and basic mental processes develop. The high intensity of the process of personality formation during preschool childhood makes it especially effective to carry out pedagogical interaction with the child and solve the problems of his development, education and training [1, p. 39].

At the same time, children develop a more loyal attitude towards work, interest in the work of adults, and hard work. Education and upbringing are usually in one whole: teaching, we educate, and educating - we teach.

At the same time, teaching and upbringing as a kind of aspects of a single process have their own composition, their own specific methods, their material and psychological prerequisites. In the early stages of children's life, education and upbringing appear in a closer unity, and it is difficult to differentiate them, but as the child grows up, upbringing and education become more and more clearly differentiated. But this does not mean at all that teaching loses its educational power, and education ceases to be teaching. Teaching at all stages of a child's development remains upbringing, and upbringing remains teaching [2, p. 55].

The principles of teaching are such initial positions that the educator uses during the selection of the content, organization and methods of teaching. They reflect the internal natural aspects of the activities of the educator and the child, determine the effectiveness of training at different age stages with different forms of organization of training.
The principles of teaching are not once and for all accepted categories. As psychological and pedagogical science develops, they improve, acquiring a deeper justification (the principle of active learning, developmental learning, etc.) [3, p. 101].

The organizational form of teaching is classes that differ from lessons at school in structure, less stringent requirements, a greater degree of cooperation between the teacher and children. The main feature of training sessions with preschoolers is that cognitive activity is based on the child's practical, mental actions and mental actions with prompts. However, the general laws and principles of teaching preschool children and primary school children are the same. Knowledge of these principles ensures the productivity of solving educational, upbringing and developmental problems.

The success of the learning process largely depends on the provisions that guide the teacher in his organization. These provisions or laws of teaching were called in pedagogy didactic principles of teaching.

\section{METHODS}

The principles of teaching are the starting points that determine the activities of the teacher and the nature of the cognitive activity of students. Ignorance of the principles or their inept application inhibits the success of learning, makes it difficult to assimilate knowledge, the formation of the qualities of the child's personality [4, p. 28].

The set of principles makes it possible to characterize the entire educational process, all aspects of the teacher's activity and the cognitive activity of children. In practice, the following principles of teaching preschool children are used. 
Its essence lies in the fact that real knowledge that correctly reflects reality must penetrate into the child's mind. In the classroom, the educator definitely forms in children specific ideas, knowledge about the world around them, which do not conflict with those that the school will give. The student's initial scientific knowledge does not arise out of thin air, but on the basis of real ideas received by children in kindergarten. Thus, a deeper scientific knowledge of reality arises on the basis of a less deep one. Undoubtedly, it is not easy to adhere to this principle when explaining the simplest things to preschoolers. Didactics is designed to prepare educational material in such a way that, on the one hand, it correctly reflects the surrounding reality, and on the other, it would be understandable and accessible to children. The scientific principle ensures the formation of elements of dialectical - materialistic understanding of the surrounding world in preschool children [5, p. 64].

The importance of this principle is determined by the specific specifics of the child's thinking in kindergarten. The principle of visibility is not new. At the same time, it is possible that in the process of a child's development, qualities are formed in him that are directly opposite to those that we would like to see.

The period of preschool childhood is a favorable time for the gradual formation of the foundations of a scientific worldview in a child, that the knowledge, experience of activity, attitude, behavior acquired at this age stage all this, taken together, prepares in the child that qualitative leap that occurs in the process of forming a worldview on later age stage schooling.

It is no coincidence that children strive to translate any story into a figurative language, to imagine events in the form of some kind of visual picture. The most difficult thinking skills reasoning, counting, proving, analyzing and comparing - come from initial external actions, from working with specific objects. To learn to count in your head, you have to work hard, counting real objects. Real objects and visual images contribute to the correct organization of the mental activity of children. The value of visualization of learning is convincingly confirmed by studies, which show that basic information is assimilated by a person through visual and auditory perception. Visual information is perceived instantly. Auditory information enters our brain sequentially and takes much longer [6, p. 77].

Implementing the principle of visibility in the pedagogical process of kindergarten means enriching and expanding the child's direct sensory experience to clarify his empirical knowledge.

In preschool institutions, the following types of visualization are used in the learning process:

\section{Subject;}

2. Figurative;

3. Conditionally - symbolic clarity.

Using objective visualization, I show children natural objects of the outside world, volumetric images (toys, models, dummies of vegetables, fruits).

When using figurative clarity, I show children pictures, illustrations, slides.

When using conditional - symbolic visualization, mathematical signs, schemes of words, sentences, tables for studying the composition of numbers are demonstrated.

In teaching children in the classroom, visualization is used, first of all, in connection with communicating new knowledge to children, as well as when consolidating them, when organizing independent activities of children. 
The following requirements are imposed on the visibility used in the classroom: they must fully reflect everything around, correspond to the level of development of preschoolers, be highly artistic in content and design,

What the teacher of children teaches should be clear to him and also definitely correspond to the development of the child.

To master the literacy, the child must learn to distinguish the phonetic side of the text. In addition, children at this age are characterized by physiological inarticulateness (they cannot pronounce hissing, whistling sounds, etc.), which means that they cannot be prepared for direct literacy training.

An essential feature of the principle of accessibility is the connection between the acquired knowledge and those that have already been formed in the child's mind. If such a connection cannot be established, then knowledge will be inaccessible to children [7, p. 26].

However, what is available in teaching children cannot be exemplified with light. Easy training does not cause any mental effort, stress in children, and, therefore, does not contribute to their development. Accessible teaching always presupposes setting for children such tasks, such tasks, the solution or implementation of which would be within the reach of the children and at the same time cause some strain on their mental strength.

Experimental data show that if children do not show interest in learning, then the information coming from teacher to child is not perceived by them. Even with a neutral mental state of the child, information coming from the outside is not perceived by the child's brain.

The practice of kindergarten shows that many children are intellectually passive due to the fact that the teacher, when explaining the educational material, does not foresee in advance the techniques that activate the cognitive abilities, thinking and behavior of the child, when he "chews" everything down to the smallest details himself, without relying on activity and independence of the child, who has nothing to do but "swallow" the next dose of material.

Consistency presupposes the study of educational material in such a way that the assimilation of a new one would be based on the knowledge that children have and prepare a further stage in the cognitive activity of children. The educator, on the basis of the program, determines and prepares the next "dose" of educational material for assimilation. Each such "dose", part of the educational material is presented in conjunction with the previous ones, in complication.

The principle of connection with life follows from the dialectical-materialist law of the unity of theory and practice. Of course, the connection to life for young children is limited by their capabilities. Their life is a game, work, occupation. The acquired knowledge should be used in the specified activities.

Children of preschool age differ from each other in everything, and in the speed of thinking, behavior, etc. Individual differences in children are explained by different natural characteristics, as well as different living and upbringing conditions.

The main way to study the characteristics of preschool children is systematic observation of the child; individual and group conversations; assessment of the results of their fulfillment of tasks, etc. The purpose of the study is to prevent and overcome the existing shortcomings in the mental and moral development of the child, relying on the positive qualities of the individual.

The educator must know what each child is capable of. Some of the 25 - 30 children quickly grasp the educational material, and who - 
slowly. You cannot demand the impossible from a preschooler. It is necessary to study the personality of the child, to look closely at him, to reveal his character.

An individual approach is used to create conditions for the all-round development of each child and to prevent the influence of unpleasant circumstances on his development. So, children with impaired vision and hearing in the classroom are seated closer to the teacher, closer to the visual aids, so that they better hear the explanation and see well the demonstration of the sample, demonstration material.

The educator restrains impulsive children with weak inhibitory reactions, developing their will. Some children, especially those who have just come to the kindergarten, often have a slow speech, insufficient vocabulary. Such children should not be rushed when answering, telling. It is necessary to cultivate a benevolent attitude towards them on the part of comrades.

In kindergarten, there are children who do not have the habit of mental work, they like to play, but are reluctant to study. It is these children who need to be given the opportunity to experience the joy of success, which will increase their interest in the content of the lesson, in mental work [5, p. 93].

In the work of the educator, the following parameters of the child's personality are taken into account:

1. The nature of the switching of mental processes;

2. Level of knowledge and skills;

3. Working capacity;

4. Level of independence and activity;

5. Attitude to learning;

6. Level of volitional development.

Guided by didactic principles, you can achieve better results in teaching preschool children.
Thus, the above-mentioned principles of teaching give the unity of the teacher's practical activity and the cognitive activity of children. Methods, content, organization of training sessions with preschool children are significantly dependent on the teacher's understanding of the principles of teaching and the ability to apply them in their activities [7, p. 52].

\section{Foreign experience of teaching preschool children}

In foreign pedagogy, the solution to the problem of interaction between the family and the preschool institution differs significantly from the solution of the same issue in Russian pedagogy. There, the child and his family are in the center of attention, and the interaction of the preschool institution with the parents is seen as helping parents in raising the child, and not as teaching parents what teachers know [9].

In England, there are public (free) and private preschool institutions. They are subordinate to the authorities in charge of primary and secondary education. There are no official instructions regarding the content of the work or programs. Employees of preschool institutions draw up programs independently, taking into account the recommendations that are given at special conferences and courses. The guiding principles in the work of preschool institutions are the child's self-expression in activities as the best means of identifying abilities and setting for their spontaneous, spontaneous development [10].

In the United States, there is also no single preschool education program, no single state system, no general laws, so work in each state is structured differently. In the United States, preschool institutions are different: public kindergartens at public schools, universities, colleges, private kindergartens and child 
centers. The concept of preschool education is largely based on the pragmatic pedagogy of J. Dewey. In accordance with it, independent activity of children prevails in preschool institutions, games with building materials are widely used. Much attention is paid to teaching children the ability to independently plan their work, carry it out carefully, and bring it to the end. Children are taught to be leaders [10].

There are also public and private preschools in France. They were included in the public education system in 1982, while the state ones are free and secular, and the private ones, which are attended by the children of wealthy parents, work according to different educational programs.

The abundance of educational programs and the focus of preschool education primarily on the family, and not on society as a whole, find expression in different pedagogical approaches to the interaction of the family and the preschool institution. The following models of interaction with parents can be distinguished: the Adler model, the educational-theoretical model, the model of sensory communication, the model based on the transactional analysis of E. Bern, the model of group consultations by $\mathrm{H}$. Jinota, etc. [9].

\section{CONCLUSION}

Thus, in order for the teaching of preschool children to be effective and bring good results, it is enough to observe the basic principles of teaching:

1. The principle of learning in play. Play activity in preschool age is the leading activity. Therefore, it is most effective to conduct training sessions in a playful way.

2. Classes should be interesting for children and in an active manner. If the classes are interesting to the child, he actively takes part in them and thus knowledge is assimilated faster and more reliably.

3. The principle of visibility. In working with babies, this teaching principle is one of the leading. The preschooler is still dominated by visual-figurative thinking. This is why it is so important to provide your child with visual examples and material.

4. The principle of consistency. Learning should be consistent, that is, knowledge is given from simple to complex, and not vice versa.

5. The principle of accessibility and individuality. This means that knowledge and skills should be given to a child, taking into account his age and individual characteristics.

Compliance with these principles will help the baby to develop harmoniously and effectively.

\section{REFERENCES}

1. Kozlova, S.A. Doshkolnaya pedagogika / S.A. Kozlova - M.: Vlados, 2003. - 400s.

2. Kolesnikova, I.A. Vospitaniye chelovecheskix kachestv / I.A. Kolesnikova // Pedagogika. - №7. - 1998. - S. 55 - 58.

3. Avanesova, V.N. Teoreticheskiye osnovi zanyatiy kak forma umstvennogo vospitaniya i obucheniya: Soderjaniye i metodi umstvennogo vospitaniya doshkolnikov / V.N. Avanesova - M.: Prosvesheniye, 1980. - 200s.

4. Pijyanova, L. Kak pomoch rebenku $v$ period adaptatsii / L. Pijyanova // Rebenok $v$ detskom sadu. - №2. - 2003. - S. 21- 28.

5. Loginova, V.I. Doshkolnaya pedagogika / V.I. Loginova, N.G. Samorukova - M.: Prosvesheniye, 2000. - 250 s.

6. Karalashvili, Ye.A. Vzaimodeystvuyem so spetsialistami / Ye.A. Karalashvili, N.Ye. Malaxova // Spravochnik starshego vospitatelya doshkolnogo uchrejdeniya. №7. - 2010. - S. $74-78$. 
The American Journal of Social Science and Education Innovations (ISSN - 2689-100x)

Published: December 18, 2020 | Pages: 93-99

Doi: https://doi.org/10.37547/tajssei/Volume02Issue12-17

7. Lagunov, Yu.A. Doshkolnoye obrazovaniye: uchebn. posobiye dlya stud. vissh. ucheb. zavedeniy / Yu.A. Lagunov SPb.: Pervoye sentabrya, 2000. - 400s.

8. Remezova, A.S. Skoro v shkolu / A.S. Remezova // Rebenok v detskom sadu. №5. - 2005. - S. 35 - 37 .

9. http://detstvo.ru

10. www.doshkolniki.org 